\title{
COMPOSITE FILMS BASED ON PUMPKIN OIL CAKE OBTAINED BY DIFFERENT FILTRATION PROCESS
}

\author{
Nevena M. Hromiš, Senka Z. Popović, Danijela Z. Šuput, Sandra N. Bulut, Vera L. Lazić \\ University of Novi Sad, Faculty of Technology, 21000 Novi Sad, Bulevar cara Lazara 1, Serbia
}

*Corresponding author:

Phone: +381214853702

E-mail address: nevena.krkic@uns.ac.rs

\begin{abstract}
Packaging is inseparable retainer of almost all food products. However, most of produced packaging ends as packaging waste after consumption of the product. Increasing amounts of packaging waste that should be managed represents serious challenge of every modern society. There are many different approaches to address this subject, amongst which biodegradable, natural biopolymer-based or even edible packaging holds considerable potential. In this paper, a by-product of edible oil industry, left after completed extraction by cold pressing of oil from hulls of pumpkin seeds, was used to produce biopolymer packaging films. Pumpkin oil cake was used to produce composite bio-based films. Different filtration of film forming suspension was applied in order to test composite film production using different filtration fractions, leading to higher process yield and minimizing waste. In addition, films were casted on surface, about ten times larger comparing to the cast surface typically reported for these types of films in the literature, in order to test the possibility for commercial production and scale up process. Also, casted mass of film forming suspension was varied in order to define minimal casting mass per unit area. Presented results showed that biopolymer films based on the pumpkin oil cake can be successfully produced in sheets $(50 \times 35 \mathrm{~cm})$, compared to films earlier produced in the form of discs with diameter $12 \mathrm{~cm}$. Different filtration fractions from initial film forming suspension can be used for film formation, leading to increased production yield. Different filtration fractions lead to different film properties that should be adjusted according to selected application. Casted mass of film forming suspension was successfully decreased (comparing to earlier literature data) without compromising film functional properties and minimal casting mass was defined as 26 $\mathrm{g} / \mathrm{m}^{2}$.
\end{abstract}

Key words: biopolymer film, pumpkin oil cake, composite, synthesis, characterization

\section{INTRODUCTION}

Extensive research has been performed to analyse different agro-industrial waste and by-products in order to valorize and reduce waste by recovering valuable natural compounds. Extraction of active compounds, as well as different biopolymers represents just a little fragment of waste valorization approaches that are being subjected to examination (Lin et al., 2014).

One of possible utilizations of biopolymers extracted from biomass is production of natural, biodegradable, or even edible packaging (Popović et al., 2018). These re- searches are in line with ongoing campaign focused on packaging industry. The campaign is driven by different stakeholders, consumers with increasing environmental awareness, as well as national governments through legislative frame that provides for measures aimed at limiting the production of packaging waste (Directive (EU) 2018/852).

Further concern of researchers is that sole extraction process of biopolymers uses additional chemicals and energy, leaving waste that is unsuitable to be used further 
or even represents bigger environmental load than the initial waste. This is why valorization with minimum processing, appreciating environment in all segments is preferable. In the frame of these aspiration, group of researchers offered new concept of utilization of edible oil industry waste and by-products, where instead of extracting protein isolate, whole cake or meal is used to produce composite biopolymer films, which is composed of proteins, as well as polysaccharides, oil and other components present in the starting cake or meal (Kim et al., 2004; Kim et al., 2005; Popović et al., 2011; Lee and Min, 2013; Oh et al., 2016; Delgado, 2018).

Popović et al. (2011) offered solution for producing composite biopolymer film based on hull-less pumpkin oil cake that remains after completed process of cold pressing oil from pumpkin seeds. Composition of cake was determined to be 60$65 \%$ proteins, about $12 \%$ carbohydrates and $8-12 \%$ oil that remains in the cake, which is very interesting for biopolymer film production considering high content of biopolymer fibres present.

In this research, procedure proposed by Popović et al. (2011) was modified in the part of filtration to test composite film production using different filtration fractions, i.e. included particle size, leading to higher process yield and minimizing waste. In addition, films were casted on larger surface, increasing ten times produced film surface in order to test possibility for commercial production and scale up process. Also, casted mass of film forming suspension was varied to define minimal casting mass per unit area.

\section{MATERIALS AND METHODS}

The grounded hull-less pumpkin (Cucurbita pepo L. c.v. Olinka) oil cake (PuOC) was kindly supplied by „Linum“, Čonoplja, Serbia, and stored at the temperature of 4 ${ }^{\circ} \mathrm{C}$. All other reagents were of analytical grade.

The film-forming suspension of $\mathrm{PuOC}$ $(10 \%, w / w)$ was prepared in deionized water, with addition of $30 \% \mathrm{w} / \mathrm{w}$ (per weight of PuOC) glycerol and $0.2 \% \mathrm{w} / \mathrm{w}$ (per weight of polysaccharides in PuOC) guarxanthan. $\mathrm{pH}$ value of the obtained film for- ming suspension (FFS) was adjusted to 12.0 using $0.2 \mathrm{M} \mathrm{NaOH}$ and the FFS was incubated at $90{ }^{\circ} \mathrm{C}$, for 20 minutes (Popović et al, 2011). Hot FFS was filtrated through nylon filter (pores around $100 \mu \mathrm{m}$, PA13XXX, Saati Tech, Milano, Italy) to obtain finer filtration (FF) fraction of FFS and through cheesecloth (around $800 \mu \mathrm{m}$, Clearstream Filters Inc., Delhi, Ontario) to obtain rougher filtration (RF) fraction of FFS. When FF fraction was obtained, production yield amounted around $50 \% \mathrm{w} / \mathrm{w}$, while for RF fraction, production yield was $90 \% \mathrm{w} / \mathrm{w}$. Obtained suspensions were poured onto Teflon coated flat glass surface $(350 \mathrm{~mm} \times 500 \mathrm{~mm})$ to cast films. Casted mass of FFS was varied: $300 \mathrm{~g}$, $250 \mathrm{~g}, 200 \mathrm{~g}$, and $150 \mathrm{~g}$ in order to define minimal necessary casting mass to surface ratio. Under $150 \mathrm{~g}$ of FFS it was impossible to cover the surface for casting. Films were air dried for 2 days at room conditions. Dry films were peeled of the glass surface, visually examined and formed into adequate sample size for diferent property examinations. Before testing tensile properties, as well as water content of films, samples were conditioned during at least $48 \mathrm{~h}$ in two different atmospheres: temperature $(23 \pm 3){ }^{\circ} \mathrm{C}$, $R H=50 \pm 5 \%$ for room condi-tions (R) and temperature $(6 \pm 2){ }^{\circ} \mathrm{C}, R H=50 \pm 5 \%$ for refrigerated conditions $(F)$.

Film thickness was measured using a micrometer Digico 1, with sensitivity of 0.001 $\mathrm{mm}$ (Tesa, Renens, Switzerland). Eight thickness measurements were carried out.

Tensile strength (TS) and elongation at break $(E B)$ were measured on the Instron Universal Testing Instrument Model No 4301 (Instron Engineering Corp., Canton, MA), according to ASTM standard method D882-10. A rectangular film strip of $90 \mathrm{~mm}$ in length and $15 \mathrm{~mm}$ in width was used. Prior to testing, strips were conditioned during at least $48 \mathrm{~h}$ in two different atmospheres, room conditions and refrigerated conditions. The initial grip separation was set at $50 \mathrm{~mm}$, and crosshead speed was set at $50 \mathrm{~mm} \cdot \mathrm{min}^{-1}$. TS and EB measurements were repeated at least five times for each storage condition.

For water content determination, film samples $(2 \times 2) \mathrm{cm}$ were conditioned in dif- 
ferent starting atmospheres during $48 \mathrm{~h}$ (room and refrigerated conditions). Film samples were weighed $\left(w_{1}\right)$, dried at 105 ${ }^{\circ} \mathrm{C}$ for $24 \mathrm{~h}$ and weighted $\left(\mathrm{w}_{2}\right)$ again. Water content $(W C)$ was determined as the percentage of initial film weight lost during drying and reported on a wet basis (Eq. 1) (Rhim et al., 2002).

$W C[\%]=\frac{\left(w_{1}-w_{2}\right) \times 100}{w_{1}}$

Triplicate measurements of water content were conducted for each storage condition.

Swelling ability was determined on the pieces of films $(1 \times 2) \mathrm{cm}$ in size, which were weighed in air-dried conditions, $\left(w_{1}\right)$. They were then immersed in deionized water $\left(25^{\circ} \mathrm{C}\right)$ for $2 \mathrm{~min}$. Wet samples were wiped with filter paper to remove excess liquid and weighted $\left(w_{2}\right)$. The amount of adsorbed water was calculated as shown in Eq. (2)

$$
\text { Swelling ability }[\%]=\frac{\left(w_{2}-w_{1}\right) \times 100}{w_{1}}
$$

where $w_{2}$ and $w_{1}$ were the weights of the wet and the air-dried samples, respectively (Bigi et al., 2004). Swelling ability was also tested in $p H=4, p H=7$ and $p H=9$ buffers. Each measurement was repeated at least three times.

For total soluble matter determination, small pieces of film $(2 \times 2) \mathrm{cm}$ were dried in the oven at $105{ }^{\circ} \mathrm{C}$ for $24 \mathrm{~h}$ to obtain the initial dry mass of the film. After drying, films were placed into test tubes containing $20 \mathrm{~mL}$ of deionized water. Test tubes were covered and gently shaken and left at room temperature, for $24 \mathrm{~h}$. The remaining pieces of film were dried in the oven at $105^{\circ} \mathrm{C}$ for $24 \mathrm{~h}$ to obtain final dry mass of the film. The percentage of total soluble matter (\% TSM) of the films was calculated using the Eq. (3).

$\operatorname{TSM}[\%]=\frac{\left(w_{1}-w_{2}\right) \times 100}{w_{1}}$

where $w_{1}$ and $w_{2}$ are initial dry mass before the test and final dry mass after the test. Test was repeated on each sample in minimum three replications (Popović et al., 2011).

Moisture barrier properties of films were determined gravimetrically (dish method), according to the ISO 2528:1995, condition A (temperature $25{ }^{\circ} \mathrm{C} \pm 1{ }^{\circ} \mathrm{C}$ and relative humidity $90 \% \pm 2 \%$, obtained by saturated solution of potassium nitrate). Silica gel was used as desiccant for filling the test dish. Three replicates were tested simultaneously.

Light transmission was measured by using a T80+ UV-VIS Spectrometer (PG instruments LTD). The scanned wavelength range was 200-800 $\mathrm{nm}$. The light transmission was measured on flat sample piece $15 \mathrm{~mm}$ x $50 \mathrm{~mm}$. Three replications per sample were measured.

Statistical analysis was carried out using OriginPro 8 (OriginLab Corporation, Northampton, MA, USA). All data were presented as mean value with their standard deviation indicated (mean $\pm S D$ ). Variance analysis (ANOVA) was performed, with a confidence interval of $95 \%(p<0.05)$. Means were compared by the Tukey test.

\section{RESULTS AND DISCUSSION}

The obtained films are shown in Fig 1. FF films (left) were barely transparent observed visually in transmitted light. Tactile observation was that films were smooth, soft and flexible, while visually films appeared glossy, light green with a hint of yellow hues. Mild aroma of pumpkin cake was registered. RF films appeared opaque, green, with yellow, dark green and black residues from the cake in the form of solid points. Upper side of the film (in contact with air during drying) was rough, while lower side was smoother. With increasing mass of casted film forming suspension, films appear visually less transparent and greener.

Film thicknesses, as well as uniformity of thickness figures are properties that affect many functional properties of films, amongst which mechanical and barrier properties. From the results for thickness of films, shown in Figure 2, it can be seen that, both film suspension casted mass ( $g$ ) and type of filtration affected this property. With growing mass of casted film forming suspension, thickness of films increased, as expected. This effect is more pronounced in RF films, compared to FF films. 


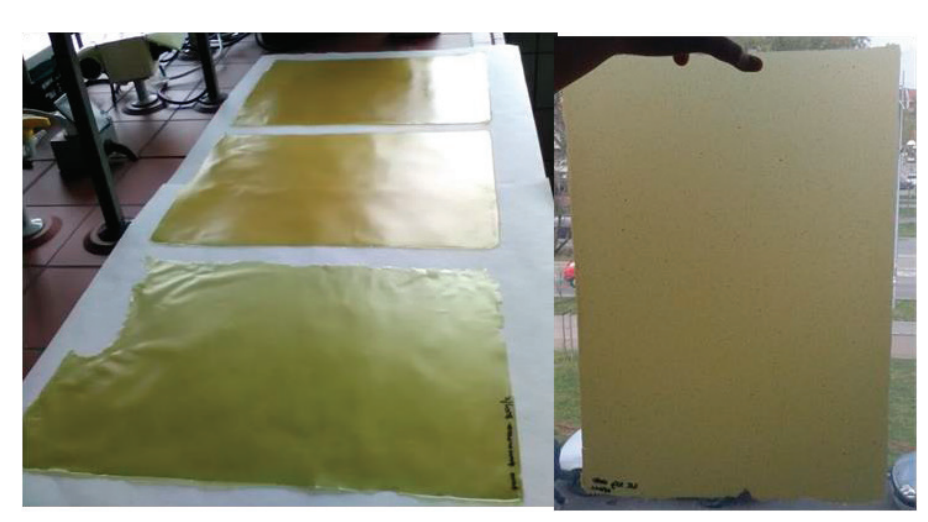

Figure 1. Appearance of FF films (left) and RF films (right)

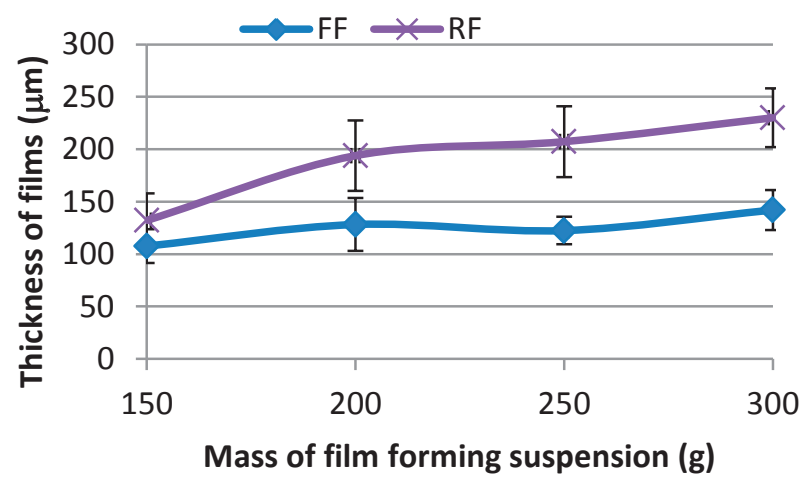

${ }^{a, b, c, d}$ Different letters denote significantly different means with $95 \%$ probability $(p<0.05)$

Figure 2. Thickness of PuOc films ( $\mu \mathrm{m})$

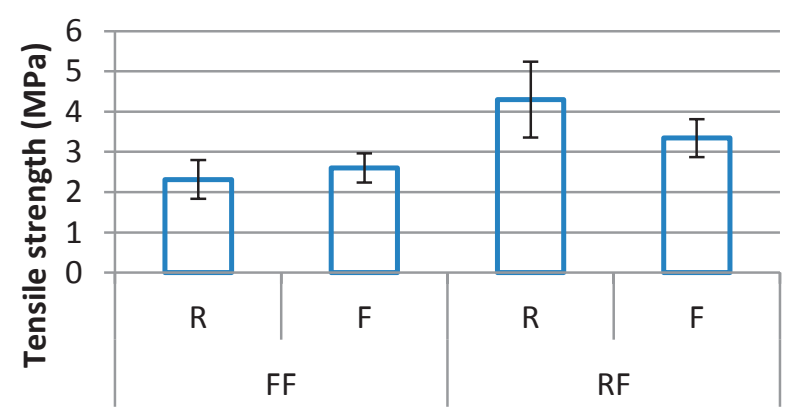

Film

${ }^{\mathrm{a}, \mathrm{b}, \mathrm{c}}$ Different letters denote significantly different means with $95 \%$ probability $(p<0.05)$

Figure 3. Tensile strength of films (MPa), where R represents films at room conditions and $F$ represents films at refrigerated conditions

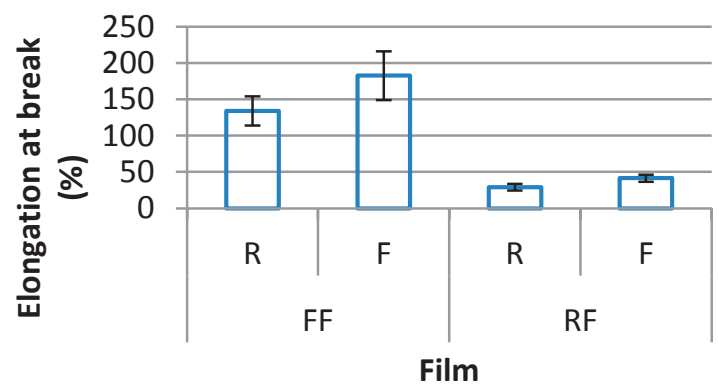

${ }^{a, b, c}$ Different letters denote significantly different means with $95 \%$ probability $(p<0.05)$

Figure 4. Elongation at break of films (\%), where R represents films at room conditions and $\mathrm{F}$ represents films at refrigerated conditions 
Further, RF films showed higher thickness values than FF films for the same casted film forming suspension mass.

Mechanical properties of films are very important in packaging material manipulation during storage, transport and packaging process, as well as during whole shelf life and consume phase of the product. Mechanical properties give insight in the possibility of film to protect physical integrity of packed product (Martins et al., 2012; Rubilar et al., 2013). Different biopolymer-based films, depending on base polymer properties, applied production process, plasticizers and additives show different mechanical properties. As shown in Figure 3, tensile strength of films obtained by different filtration procedure was different $(p<0.05)$. Higher values for tensile strength of RF films (4.30 MPa), compared to FF films (2.32 $\mathrm{MPa})$ were probably due to additional interactions between components present in the RF films and lacking in the FF ones. Literature data for tensile strength of composite films obtained from meals and cakes left after oil extraction varied considerably, from 1.6 $\mathrm{MPa}, 3.2 \mathrm{MPa}$ and $12 \mathrm{MPa}$ for films obtained from defatted soybean meal (Kim et al., 2005; Lee and Min, 2013; Oh et al., 2016), over 6.8 MPa for pectin/soy-flour based films (Mariniello et al., 2003) to 24$59 \mathrm{MPa}$ for pectin-fish skin gelatine or pectin-soy flour protein composite films (Liu et al., 2007)

Mass of casted filmogenic suspension did not affect elongation at break values significantly, so average values for each filtration type was presented in Fig. 4, where error bars include films obtained by casting different mass of FFS (150 g-300 g). Elongation at break values for differently filtrated films are significantly different $(p<0.05)$, amounting $133.9 \%$ for FF films and $29.1 \%$ for RF films. These results are in accordance with the results obtained for tensile strength, where additional interactions between components present in the RF films affect film mechanical properties in a way that films become stronger, but less extensible. In comparison to literature data for elongation at break of composite films based on defatted oilseed meals and cakes, the tested
PuOC films showed higher elongation at break values than most composite films (Mariniello et al., 2003; Liu et al., 2007; Lee and Min, 2013; Oh et al., 2016). Effect of different storage conditions (room or refrigerated) on mechanical properties of analyzed films was significant $(p<0.05)$. Tensile strength of RF films was lower when films were conditioned in the refrigerator before testing, while for FF films, elongation at break was higher for the films from refrigerator. This effect may be correlated with different water absorption properties of films under different temperatures. Biopolymers suspended and dissolved in the PuOC filmogenic suspension, as well as glycerol as the plasticizer are hygroscopic and therefore film moisture content is affected by ambient conditions, relative humidity and temperature. Water, as the main solvent in the natural biopolymer technology increases the free volume of biomaterials, and thus is considered as additional plasticizer. Absorbed water, as well as glycerol, acts as plasticizers and as lubricant of the polymer chains allowing fibers to slide one over the other, improving flexibility (Vieria et al., 2011). The plasticization action of water molecules on biopolymers has been widely reported in the literature (Vieria et al., 2011).

In this research, higher water content was recorded in the films conditioned in the refrigerated conditions, compared to the room conditioned ones. Also, water content was higher in the FF films, compared to the RF ones under room conditions (Figure 5). These results are in good correlation with mechanical properties of the films, where water absorbed in the film probably acted as additional plasticizer.

During initial hydration from the dry state, a biopolymer film experiences improved film elasticity as a result of diffusion of small water molecules between long polymer chains, widening polymer network and decreasing intensity of polymer-polymer interaction. With increasing hydration, film elasticity and cohesiveness decreases progressively because water-polymer interactions develop to the detriment of polymer-polymer bonds. In a 3-phase system (water-plasticizer-polymer), the pre- 
sence of the second plasticizer normally has a deciding influence on the plasticizing action of the primary one (Lourdin et al., 1997).

Important properties of produced biopolymer films are swelling degree and solubility. In contact with appropriate solvent, films swell. When dry hydrocolloid based films are brought into contact with water, water molecules are drawn by hydrophilic nature of film surface and penetrate into film matrix, bonding to polar groups in hydrocolloid molecules, separating fibres and widening polymer network. Swelling degree of analyzed films (figure 6) was approximately $100-150 \%$, except FF film in water (204.3\%). Values are in accordance with values obtained for this type of film (Popović et al., 2011). On the other hand, swelling degree is considerably lower than in gelatine, soy protein based films as well as their composites, more similar to the values obtained for collagen films (Popović, 2013; Hromiš, 215; Cao et al., 2007). These results suggest strong intermolecular interactions between biopolymer molecules in PuOC based films. Highest values for film swelling were obtained in water and lowest in $\mathrm{pH} 4$ buffer solution. In water and $\mathrm{pH} 9$ solution, swelling degree of FF films was higher $(p<0.05)$ then RF films. This difference might be due to stronger interactions and possible crosslinking effect of components additionally present in RF films, similar as in mechanical properties.

Results for dissolution of films were in correlation with swelling of films, as well as mechanical properties. FF films were more soluble than RF films, probably due to stronger interactions and cross-linking effect of components present in RF films. Values for solubility of PuOC films in water are in accordance with most hydro-colloid based films, between 30-40\% (Choi and Han, 2001; Bamdad et al., 2007; Hromiš, 2015).

Barrier property of casted PuOC films toward water vapor is presented in Fig. 7. Increasing mass of casted FFS from $150 \mathrm{~g}$ to $300 \mathrm{~g}$ did not affect this property significantly in FF films $(p>0.05)$. Values for water vapor transmission rate (WVTR) of these films ranged from $385.03 \pm 32.17$ $\mathrm{g} / \mathrm{m}^{2} 24 \mathrm{~h}$ for FF150 film to $349.68 \pm 15.04$ $\mathrm{g} / \mathrm{m}^{2} 24 \mathrm{~h}$ for FF250 film and $353.10 \pm 34.73$ $\mathrm{g} / \mathrm{m}^{2} 24 \mathrm{~h}$ for FF300. In RF films, decrease of WVTR can be noticed with increase in casted mass of FFS, i.e. film thickness. Also, for same masses of casted FFS, RF films show lower WVTR, compared to FF films. However, if WVTR (shown in fig.7) is recalculated to permeability, presented values would correspond to permeability of (14.4-17.4) $\mathrm{gmm} / \mathrm{m}^{2} 24 \mathrm{~h} \mathrm{kPa}$ for the $\mathrm{FF}$ films, while for RF films these values would amount 13.2-18.4 gmm/ $\mathrm{m}^{2} 24 \mathrm{~h} \mathrm{kPa}$.

Considering this, it can be concluded that differences in WVTR were mostly due to differences in thickness between RF and FF films, and that films with normalized thickness showed similar water vapor permeability. Values for water vapor permeability of tested PuOC films are comparable to gelatin based films (Bourtoom, 2006; Jongjareonrak, 2006), but lower than values reported for whey protein isolate based films (Fairley, 1996; McHugh and Krochta, 1994). When beeswax was added to whey protein isolate based films, water vapor permeability of films was lowered to the values comparable to analyzed PuOC films (Perez-Gago and Krohta, 2001).

Another important barrier property of packaging material is light barrier property. Most extensively researched foods for photo sensibility, i.e. photo induced oxidation are dairy products and meat products. Apart from the control of present residual oxygen and properties of light source, packaging material light barrier property is one of the crucial factors that can protect food from the light induced deterioration.

Different approaches can be applied towards packaging material light barrier optimization, like: type of material (e.g. paperboard vs. transparent PET); wall thickness (Lambert-Beer's law), processing, inks, pigmentation/cavitation, metallization, incorporation of UV absorbers or attachment of labels (Bertelsen and Skibsted, 1987; Bohner et al., 2014; Boh-ner and Lieblihner, 2016; Intawiwat et al., 2012; Mortensen et al., 2002). It can be noted from Figure 8 that increasing mass of casted film forming suspension influen- 


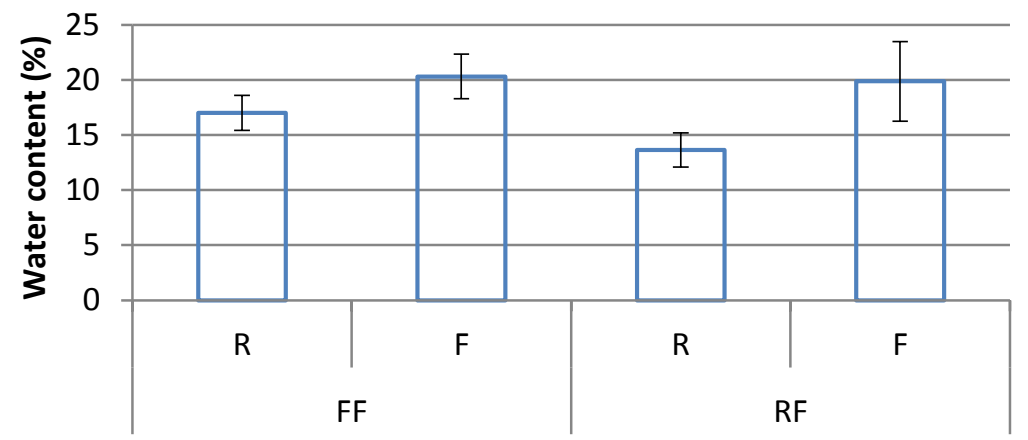

Film

${ }^{a, b, c}$ Different letters denote significantly different means with $95 \%$ probability $(p<0.05)$

Figure 5. Water content (\%) of films conditioned at room $(R)$ or refrigerated conditions $(F)$
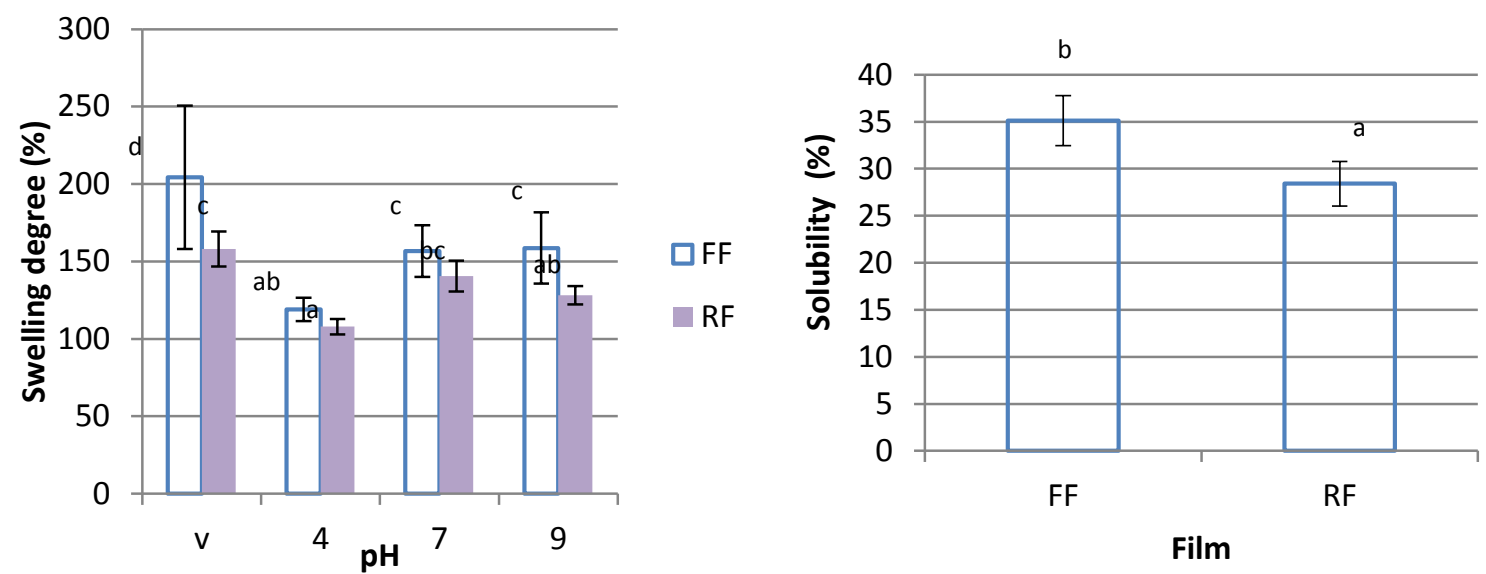

a,b,c,d Different letters denote significantly different means with $95 \%$ probability $(p<0.05)$

Figure 6. Film swelling degree (\%) (left) at different $\mathrm{pH}$ and film solubility (\%) (right) in water

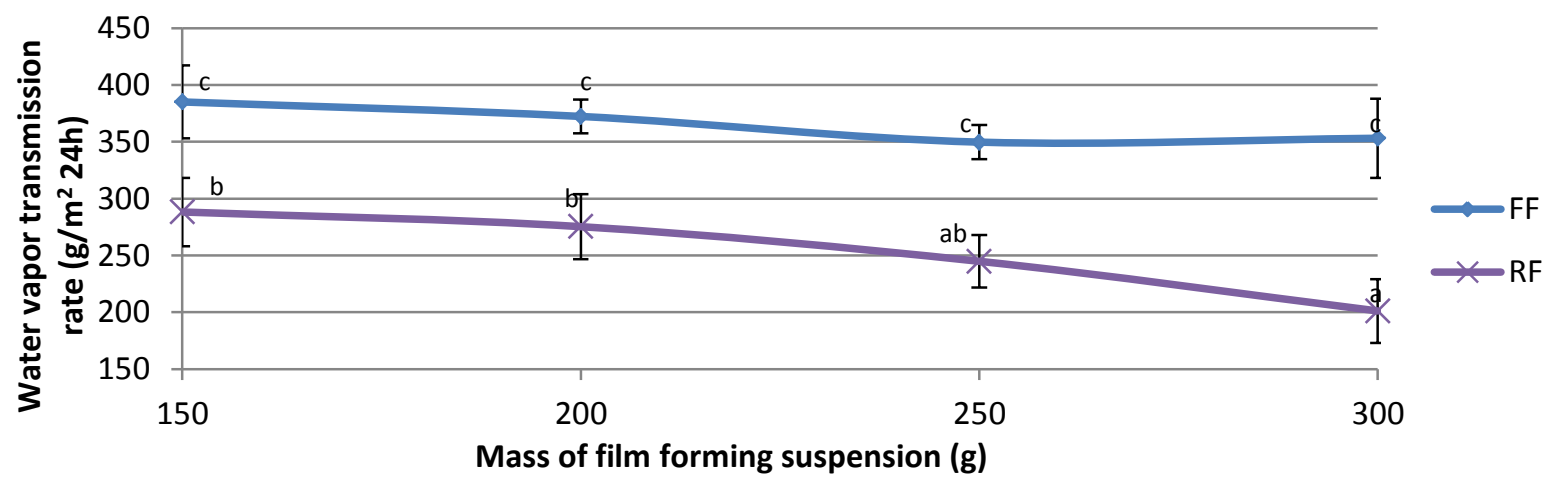

${ }^{a, b, c}$ Different letters denote significantly different means with $95 \%$ probability $(p<0.05)$

Figure 7 . Water vapor transmission rate $\left(\mathrm{g} / \mathrm{m}^{2} 24 \mathrm{~h}\right)$ of films

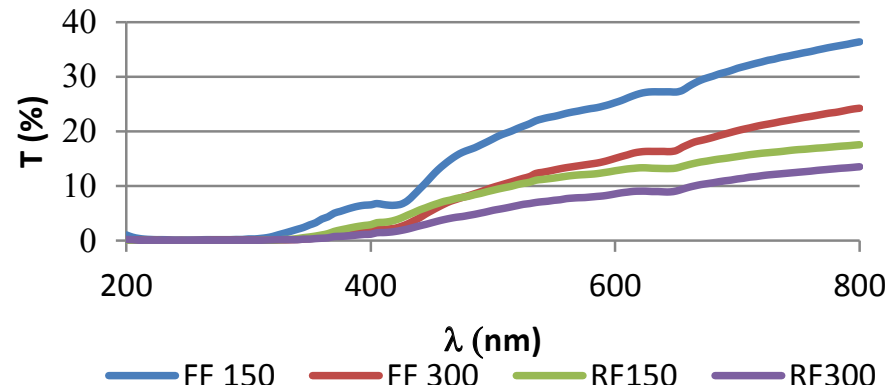

Figure 8. Light transmission spectra of the analyzed films 
ced the obtained film light transmission spectra in a way that shear of transmitted light decreased. This can be also related to growing film thicknesses (LambertBeer's law). When the same mass of FFS was casted, RF films showed considerably lower shear of transmitted light, above 300 $\mathrm{nm}$.

Even RF150 film showed better light barrier properties compared to FF 350 film in the spectral range $450-800 \mathrm{~nm}$. Below 300 $\mathrm{nm}$, transmission of light through all the tested PuOC based film was negligible. Between 300-350 nm only FF150 film started to give some transmission values (about $3 \%$ ). This property is very important for food packaging materials, because this far UV part of the spectrum is the most harmful one.

As Bertelsen and Skibsted (1987) reported, analysis of meat color photo stability showed that UV-light of wavelength around $254 \mathrm{~nm}$ is more than 4000 times efficient in $\mathrm{MbO}_{2}$ photo oxidation, comparing to yellow light $(546 \mathrm{~nm})$. Near UV wavelengths compared to the yellow light, showed 150 times higher influence in color deterioration for $313 \mathrm{~nm}$ light, 50 times for $334 \mathrm{~nm}$ light, about 10 times for $366 \mathrm{~nm}$ and $405 \mathrm{~nm}$ light, and 3 times for $436 \mathrm{~nm}$ light (Bertelsen and Skibsted, 1987). When light transmission property of films tested in this research was analyzed, it can be said that the obtained films are suitable for meat and meat products packaging materials. Transmission of the most harmful wavelengths responsible for meat products photo oxidation was less than $15 \%$ for all the films except FF 150, for which maximal transmission reached $25 \%$ in the spectral range $200-600 \mathrm{~nm}$, where most of meat photosensitizers have their absorption maximums (Bohner et al., 2014; Bohner and Lieblihner, 2016).

When dairy products are concerned, photosensitizers, such as riboflavin, porphyrin, and chlorophyll, responsible for photooxidation in dairy products absorb mostly UV and blue light below $500 \mathrm{~nm}$, but also yellow (560-590 nm), orange (590-635 $\mathrm{nm})$, and red (635-750 $\mathrm{nm}$ ) lights have been reported to cause off-flavors in dairy products. Green light (500-560 nm) has been shown to give less deterioration to sensory quality and nutrition value in dairy products compared with other colors in visible light (Intawiwat et al., 2012). The films obtained in this work can be regarded as appropriate for dairy products also, because in the whole spectral range, maximal transmission values ranged from $13.5 \%$ for the RF 300 film to $36.4 \%$ for the FF150 film.

Light transmission properties of tested films are comparable to LDPE films with added pigments and additives to improve light barrier properties of LDPE intended for dairy products packaging. Also, this property was most alike to oriented polyamide/polyethylene white film, superior to oriented polyamide/linear low density polyethylene, oriented polyamide /polyethylene and polyester/polyvinylidene chloride/polyethylene, as well as transparent LDPE film and LDPE film with yellow and silver pigment (Mortensen et al., 2002; Intawiwat et al., 2012).

\section{CONCLUSIONS}

The presented results showed that biopolymer films based on the pumpkin oil cake can be successfully produced in sheets $(50 \times 35 \mathrm{~cm})$, compared to earlier produced films in the form of discs with diameter $12 \mathrm{~cm}$. Different filtration fractions from initial film forming suspension can be used for film formation, leading to increased production yield. Different filtration fractions lead to different film properties that should be adjusted according to selected application. FF films were thinner, less strong, but more elastic then RF films, with higher water sensitivity. FF films showed higher values for water vapor transmission, as well as light transmission properties. Casted mass of film forming suspension was successfully decreased (comparing to earlier literature data) without compromising film functional properties and minimal casting mass was defined as $26 \mathrm{~g} / \mathrm{m}^{2}$.

\section{ACKNOWLEDGEMENTS}

This paper is a result of the research within the project TR 31032, financed by the Ministry of of Education, Science and Technological development, Republic of Serbia. 


\section{REFERENCES}

1. ASTM D882-10 (2010). Standard Test Method for Tensile Properties of Thin Plastic Sheeting. American Society for Testing and Materials International, West Conshohocken, Pennsylvania.

2. Bamdad, F., Goli, A.H., Kadivar, M. (2006). Preparation and characterization of proteinous film from lentil (Lens culinaris): Edible film from lentil (Lens culinaris). Food Research International, 39, 106-111.

3. Bertelsen, G., Skibsted, L.H. (1987). Photooxidation of oxymyoglobin. wavelength dependence of quantum yields in relation to light discoloration of meat. Meat Science, 19, 243-251.

4. Bigi, A., Panzavolta, S., Rubini, K. 2004). Relationship between triple-helix content and mechanical properties of gelatin films. Biomaterials, 25, 5675-5680.

5. Böhner, N., Hösl, F., Rieblinger, K., Danzl, W. (2014). Effect of retail display illumination and headspace oxygen concentration on cured boiled sausages. Food Packaging and Shelf Life, 1, 131-139.

6. Böhner, N., Rieblinger, K. (2016). Impact of different visible light spectra on oxygen absorption and surface discoloration of bologna sausage. Meat Science, 121, 207-209

7. Bourtoom, T., Chinnan, M.S., Jantawat, P., Sanguandeekul, R. (2006). Effect of plasticizer type and concentration on the properties of edible film from watersoluble fish proteins in surimi wash-water. Food Science and Technology International, 12 (2), 119126.

8. Cao, N., Fu, Y., He, J. (2007). Preparation and physical properties of soy protein isolate and gelatin composite films. Food Hydrocolloids, 21, 1153-1162.

9. Choi, W.S., Han, J.H. (2001). Physical and mechanical properties of pea-protein-based edible films. Journal of Food Science, 66, 319-322.

10. Delgado, M., Felix, M., Bengoechea, C. (2018). Development of bioplastic materials: From rapeseed oil industry by products to added-value biodegradable biocomposite materials. Industrial Crops and Products, 125, 401-407.

11. Directive (EU) 2018/852 (2018). Directive (EU) 2018/852 of the European parliament and of the Council amending Directive 94/62/EC on packaging and packaging waste. Official Journal of the European Union, L 150/141.

12. Fairley, P, Monahan, F., German, B., Krochta, J. (1996). Mechanical properties and water vapor permeability of edible films from whey protein isolate and sodium dodecyl sulfate. Journal of Agricultural and Food Chemistry, 44, 438-443.

13. Hromiš, N. (2015). Development of biodegradable active packaging material from chitosan: synthesis, optimisation of properties, characterisation and application. PhD Thesis, Faculty of Technology, University of Novi Sad, Serbia.

14. Intawiwat, N., Myhre, E., Øysæd, H, Jamtvedt, S., Kvalva, M.P. (2012). Packaging materials with tailor made light transmission properties for food protection. Polymer Engineering and Science, 52 (9), 2015-2024.

15. ISO 2528:1995 (1995). Sheet materials-Determination of water vapour transmission rate-Gravimetric (dish) method. International Organisation for Standardisation, Geneva, Switzerland.

16. Jongjareonrak, A., Benjakul, S., Visessanguan, W., Tanaka, M. (2006). Effects of plasticizers on the properties of edible films from skin gelatin of bigeye snapper and brownstripe red snapper. European Food Research Technology, 222, 229-235.

17. Kim, H.W., Kim, K.M., Ko, E.J., Lee, S.K., Ha, S.D., Song, K.B., Park, S.K., Kwon, K.S., Bae, D.H. (2004). Development of antimicrobial edible film from defatted soybean meal fermented by Bacillus subtilis. Journal of Microbiology and Biotechnology, 14 (6), 13031309.

18. Kim, H.W., Ko, E.J., Ha, S.D., Song, K.B., Park, S.K., Chung, D.H., Youn, K.S., Bae, D.H. (2005). Physical, mechanical and antimicrobial properties of edible films produced from defatted soybean meal fermented by Bacillus subtilis. Journal of Microbiology and Biotechnology, 15 (4), 815-822.

19. Lee, H., Min, S. (2013). Antimicrobial edible defatted soybean meal-based films incorporating the lactoperoxidase system. LWT - Food Science and Technology, 54, 42-50.

20. Lin, C. S.K., Koutinas, A., Stamatelatou, K., Mubofu, E., Matharu, A., Kopsahelis, N., Pfaltzgraff, L., Clark, J., Papanikolaou, S., Kwan, T.H., Luque, R. (2014). Perspective: Current and future trends in food waste valorization. Biofuels, Bioproducts and Biorefining, 8, 686-715.

21. Liu, L.S., Liu, C.K., Fishman, M., Hicks, K. (2007). Composite Films from Pectin and Fish Skin Gelatin or Soybean Flour Protein. Journal of Agricultural and Food Chemistry, 55 (6), 2349-2355.

22. Lourdin, D., Coignard, L., Bizot, H. and Colonna, P. (1997) Influence of Equilibrium Relative Humidity and Plasticizer Concentration on the Water Content and Glass Transition of Starch Materials. Polymer, 38, 5401-5406.

23. Mariniello, L., Di Pierro, P., Esposito, C., Sorrentino, A., Masi, P., Porta, R. (2003). Preparation and mechanical properties of edible pectin/soy flour films obtained in the absence or presence of transglutaminase. Journal of Biotechnology, 102, 191-198.

24. Martins, J. T., Cerqueira, M.A., Vicente A.A. (2012). Influence of $\square$-tocopherol on physicochemical properties of chitosan-based films. Food Hydrocolloids, 27, 220-227.

25. McHugh, T.H., Krochta, J. (1994). Water vapor permeability properties of edible whey protein-lipid emulsion films. Journal of the American Oil Chemists' Society, 71 (3), 307-312.

26. Mortensen, G., Sørensen, J., Stapelfeldt, H. (2002). Effect of light and oxygen transmission. Characteristics of packaging materials on photo-oxidative quality changes in semi-hard Havarti cheeses. Packaging Technology and Science, 15, 121-127.

27. Oh, Y.A., Roh, S.H., Min, S. (2016). Cold plasma treatments for improvement of the applicability of defatted soybean meal-based edible film in food packaging. Food Hydrocolloids, 58, 150-159.

28. OriginPro 8 SR2 (Scientific graphing and data analysis software) (2001). v.8.0891(B891)., OriginLab Corporation, Northampton, MA, USA (https://www.originlab.com)

29. Pérez-Gago, M., Krochta, J. (2001). Lipid particle size effect on water vapor permeability and mechanical properties of whey protein/beeswax emulsion films. Journal of Agricultural and Food Chemistry, 49, 9961002.

30. Popović, S. (2013). The study of production and characterization of biodegradable composite films based on plant proteins. PhD Thesis, Faculty of Technology, University of Novi Sad, Serbia.

31. Popović, S., Lazić, V., Hromiš, N., Šuput, D., Bulut, S. (2018). Biopolymer packaging materials for food shelf-life prolongation. In Vol. 20: Biopolymers for food design, Handbook of food bioengineering. Eds. A.M. Grumezescu, A.M. Holban, Academic Press, Elsevier, United Kingdom, pp. 223-277.

32. Popović, S., Peričin, D., Vaštag, Ž., Popović, Lj., Lazić, V. (2011). Evaluation of edible film-forming ability of pumpkin oil cake; effect of $\mathrm{pH}$ and temperature. Food Hydrocolloids, 25 (3) 470-476.

33. Rhim, J.W., Gennadios, A., Weller, C.L., Cazeirat, C., Hanna, M.A. (1998). Soy protein isolate-dialdehyde 
starch films. Industrial Crops and Products, 8, 195203.

34. Rubilar, J.F., Cruz, R.M.S., Silva, H.D., Vicente, A.A., Khmelinskii, I., Vieira, M.C. (2013). Physico-mechanical properties of chitosan films with carvacrol and grape seed extract. Journal of Food Engineering, $115,466-474$.

35. Vieira, M. G.A., da Silva, M.A., dos Santos, L.O., Beppu, M.M. (2011). Natural-based plasticizers and biopolymer films: A review. European Polymer Journal, 47, 254-263.

\title{
КОМПОЗИТНИ ФИЛМОВИ НА БАЗИ ПОГАЧЕ УЉАНЕ ТИКВЕ ГОЛИЦЕ ДОБИЈЕНИ РАЗЛИЧИТИМ ПОСТУПКОМ ФИЛТРАЦИЈЕ
}

Невена М. Хромиш, Сенка 3. Поповић, Данијела 3. Шупут, Сандра Н. Булут, Вера Л. Лазић

\author{
Универзитет у Новом Саду, Технолошки факултет, 21000 Нови Сад, \\ Булевар цара Лазара бр. 1, Србија
}

\begin{abstract}
Сажетак: Амбалажа је нераздвојни пратилац скоро сваког прехрамбеног производа. Међутим, већина произведене амбалаже, након конзумације производа, завршава као амбалажни отпад. Све веће количине амбалажног отпада који је потребно збринути представљају озбиљан изазов већине савремених заједница. Постоји много различитих приступа за ублажавање овог проблема, међу којима биоразградива амбалажа на бази природних биополимера, а међу њом и јестива амбалажа има значајан потенцијал. У овом раду је за добијање биополимерних амбалажних фрилмова коришћен отпад из индустрије уља у виду погаче уљане тикве голице, који заостаје након завршене екстракције поступком хладног цеђења уља. За производњу композитних филмова је коришћена цела погача, без изоловања појединачних компоненти. Током добијања фрилмова, коришћена су два степена филтрације у циљу испитивања производње композитних фрилмова коришћењем различитих фракција, тј. величине честица, што може довести до већег приноса процеса и додатног смањења количине заосталог отпада. Поред различитих степена фрилтрације, фрилмови су разливани на површини, око десет пута већој у односу на површину за разливање која се у литератури среће за овај тип фрилмова, како би се тестирала могућност комерцијалне производње и „scale-up“-а. Такође, маса за разливање филмогене суспензије је варирана са циљем дефинисања минималне потребне масе по јединичној површини за производњу фрилмова задовољавајућих карактеристика. Приказани резултати показују да се погача уљане тикве голице може успешно користити за добијање биополимерних композитних филмова већих димензија $(50 \times 35 \mathrm{~cm})$, што је значајно већа површина у односу на до сада анализиране филмове у облику диска пречника $12 \mathrm{~cm}$. За формирање филма могу се користити различите филтрационе фракције иницијалне фрилмогене суспензије, што може довести до повећања приноса производње. Различите фрилтрационе фракције резултују различитм особинама филма, које треба прилагодити према одабраној примени. Маса филмогене суспензије коју је могуће користити за разливање филма је смањена (у поређењу са ранијим литературним подацима) без угрожавања функционалних особина фрилмова, а минимална маса за разливање је дефинисана као $26 \mathrm{~g} / \mathrm{m}^{2}$.
\end{abstract}

Кључне речи: биополимерни филм, композитни, погача уљане тикве, синтеза, карактеризација

Received: 23 November 2018

Received in revised form: 19 December 2018

Accepted: 24 January 2019 